\title{
Biochemical Investigation of Leaf Development in Capsicum frutescens
}

\author{
Jalal Omer Ahmed ${ }^{1}$ \\ ${ }^{1}$ Industrial Crops Department, Agricultural Technical Institute of Bakrajo, Sulaimani, Iraq \\ Correspondence: Jalal Omer Ahmed, Industrial Crops Department, Agricultural Technical Institute of Bakrajo, \\ Sulaimani, Iraq. E-mail: sarkaut1983@gmail.com
}

$\begin{array}{lc}\text { Received: February 18, } 2013 & \text { Accepted: March 20, } 2013 \text { Online Published: April 15, } 2013 \\ \text { doi:10.5539/jas.v5n5p165 } & \text { URL: http://dx.doi.org/10.5539/jas.v5n5p165 }\end{array}$

\begin{abstract}
The objective of this research was to investigate the developmental regulation of cell wall components and development of leaves of Capsicum frutescens. In order to this, a growth curve was constructed of lengths and widths of fifty Capsicum frutescensleaves measured until growth had stopped (20 days). From the curve, four developmental stages were selected and harvested for further study. A range of proteins with molecular weights from 13.4 to $44 \mathrm{kDa}$ were detected in selected samples by SDS-PAGE. A total of four protein bands C, D, K and $\mathrm{L}$ with molecular weights $36.2,27.7,16.8$ and $16.0 \mathrm{kDa}$ respectively were developmentally regulated during the leaf development. This data provide the basis for further more detailed molecular analyses of leaf development in this research.
\end{abstract}

Keywords: SDS-PAGE, protein, Capsicum frutescens, leaf development

\section{Introduction}

The Capsicum genus belongs to the family Solanaceae. Species of Capsicum are used as condiments, spices, ornamentals and in pharmaceutical therapies. Capsicums are native to South America and are cultivated in warm, dry climatic conditions, but cannot tolerate frost (Barceloux, 2008; Lozzio et al., 2008). In general, Capsicum annuum is mild in taste and is used in dishes and salads. C. frutescens and C. chinese are hot and pungent owing to their unique alkaloid content. So, these species are used as hot spices in dishes and curries. Capsicum pungency is measured in terms of Scoville scale (Prasad et al., 2006). Some species like C. апnиит. 'MorokAmuba' well known as an ornamental plant in addition to edible spice (Sanatombi et al., 2010). C.frutescens is a perennial shrub which grows to a height of $1.83 \mathrm{~cm}$, have the leaves; hermaphrodite flowers and long fruits which are nutritionally and economically important. The most specialised organs are flowers that bear sepals, petals, stamens, carpels that are modified according to the climatic conditions. Various organs usually thorns, bracts, scales are derived from leaves. So, an understanding of leaf development is very important with regards to photosynthesis and respiration and many areas of plant growth and development (Byrne, 2005; Tsukaya, 2002). The cell wall provides strength, shape and allows growth to the cell. Plant cell growth occurs by the expansion of cell walls by a process named controlled polymer 'creep' (Cosgrove, 2005). The cell wall is exterior to the plasma membrane and is a part of the apoplast which is self-contagious and is present between cuticle and plasma membrane (Taiz \& Zeiger, 2002). The plant cell wall is complex and is an amalgam of carbohydrates, proteins, lignin, water and substances such as cutin, suberin and other inorganic compounds depending on the cell type, plant species and neighbour cell types. Biotic and abiotic stresses influence the structure and composition of the cell wall. Such variations can be observed in terms of growth and development, environmental sensing and signalling, plant defence, intercellular communication and selective exchange interfaces (Cosgrove, 2005). Capsicum species have high nutritional value and are an excellent source of vitamins e.g. C (ascorbic acid), A, B-complex and $\mathrm{E}$ plus minerals such as iron (Fe), molybdenum (Md), manganese (Mn), folic acid, potassium $(\mathrm{K})$ and thiamine. The Beta-carotenoids and vitamins $\mathrm{C}$ and A present in chillies are also powerful antioxidants which destroy free radicals (Simonne et al., 1997; Kothari et al., 2010). The vascular bundles play a key role in leaf and whole plant development and are scattered throughout the mesophyll tissue. Bundle sheath cells surround the phloem and xylem. Internally xylem is differentiated into tracheids, trachea, xylem paranchyma and sclerenchyma tissues which together regulate water and mineral transport. Phloem is a complex tissue of vascular bundles and its anatomy comprising of sieve tubes, companion 
cells, phloem parenchyma and blast fibres (Gamage \& Jesson, 2007). During leaf development process, 'regulated changes in extensibility (relaxation)' of the cell wall offers a balanced increase in the cell size in terms of length, width and girth of the leaves keeping the turgor pressure constant (Cosgrove, 2000; Fleming, 2002).

The objective of this study was to biochemical investigate the developmental regulation of cell wall components and development of leaves of Capsicum frutescens.

\section{Material and Methods}

\subsection{Plant Materials}

The chilli pepper plants (Capsicum frutescens) used in this investigation were grown under greenhouse conditions consisting of 16 hours of light and 8 hours of dark at temperatures of between 15 to $25^{\circ} \mathrm{C}$ from April to August 2011.

\subsection{Growth Curve and Chilli Leaf Harvesting}

The lengths and widths of fifty Capsicum frutescens (chilli) young leaves were measured and recorded on a daily basis (the chilli fruits were measured from). The chilli leaves were measured starting from lengths of 30, 31, and $32 \mathrm{~mm}$ and widths of 11, 12 and $13 \mathrm{~mm}$ until they reached their full length (growth had stopped or slowed significantly). Two growth curves were then constructed using average lengths and widths of the chilli leaves and used to select four different developmental stages of growth for further study. The chilli leaves from the selected stages were then harvested and 30mg of chilli leaves from each stage was placed into Eppendorf tubes, labelled and stored at $-20^{\circ} \mathrm{C}$.

\subsection{Extraction of Cell Wall Proteins from Chilli Leaves}

$200 \mu \mathrm{l}$ of extraction buffer (Appendix 1) was added to the Eppendorf tubes containing $30 \mathrm{mg}$ of chilli leaves and homogenised (by using Eppendorf grinder). The samples were then centrifuged at 13,000 rpm for 5 minutes and the supernatant transferred into a fresh sterile Eppendorf tube and the pellet discarded. This step was repeated. $800 \mu \mathrm{l}$ of absolute ethanol $(80 \% \mathrm{v} / \mathrm{v})$ was added to each of the $200 \mu \mathrm{l}$ samples to precipitate out carbohydrates (cellulose, hemicelluloses, pectin) and heavily glycosylated glycoproteins extensions (hydroxyproline-rich glycoproteins, HRGP) and arabinogalactin proteins (AGP's)]. The sample was then incubated overnight at $4^{\circ} \mathrm{C}$. The precipitated sample was centrifuged again at 13,000 rpm for 10 minutes. The supernatant was discarded and the pellet was re-suspended in $100 \mu \mathrm{l}$ of sterile distilled water (SDW). The protein extract was stored at $-20^{\circ} \mathrm{C}$, prior to future usage.

\subsection{Protein Assay}

$2 \mu \mathrm{l}$ of each of the protein samples (stage 1-4) were placed into a $1.5 \mathrm{ml}$ Eppendorf tube with $798 \mu \mathrm{l}$ of SDW to make a 400X dilution. $200 \mu \mathrm{l}$ of BIORAD dye reagent was added to each tube and mixed by gentle inversion of the Eppendorf tubes. $800 \mu \mathrm{l}$ of SDW and $200 \mu \mathrm{l}$ of BIORAD dye reagent was put into another Eppendorf tube and used as a control. After 10 minutes, the samples were transferred to cuvettes and the optical density of each of the samples was measured using a spectrophotometer. The absorbance for the samples was read at $595 \mathrm{~nm}$, using the control as a blank. The absorbance of each protein samples was then compared to a standard absorbance curve for Bovine Serum Albumin (BSA) (Appendix 3) to determine the protein concentration for each sample (Bio-Rad laboratories, 2005).

\subsection{SDS Polyacrylamide Gel Electrophoresis (SDS-PAGE)}

The electrophoresis cell was constructed using two $10 \times 10 \mathrm{~cm}$ glass plates which were washed with ethanol and three spacers which were placed around three slides of the plates, 1-2 $\mathrm{mm}$ from the edge. The plates were then clipped together. To prevent the leakage of separating gel, the cell was sealed with $5 \mathrm{X}$ tank buffer (appendix 2). The 4x separating gel solution was prepared (Appendix 2) and gently swirled to avoid excess aeration (which will inhibit polymerization). The separating gel solution was then immediately pipette into the electrophoresis cell, until the solution was $2 \mathrm{~cm}$ from the top of the glass plate. A layer of Butan-2-ol saturated with water was then pipette on to the top of the separating gel solution to create a level gel surface and to prevent oxygen diffusing into the separating gel solution inhibiting polymerisation. The gel was then left to polymerise for approximately 25-30 minutes. When the gel has completely polymerized, the butan-2-ol layer was poured off and the top of the gel was washed with SDW. The stacking gel solution was prepared (Appendix 2) and gently swirled. The stacking gel was then immediately pippeted onto the top of the stacking gel solution, ensuring that no air bubbles were trapped and leaving at least $1 \mathrm{~cm}$ between the bottom of the comb and the top of the separating gel. The stacking gel and separating gel were poured consecutively until these solutions reached the top of the glass plate. The comb was then placed into the solution was then left with the comb in place to 
polymerise for approximately 30-45 minutes. Once the stacking gel had polymerised, the top comb and the bottom spacer were removed and the electrophoresis cell was clipped into the electrophoresis tank. The bottom compartment was then filled with tank buffer (Appendix 2) and the electrophoresis cell was lowered into the bottom tank buffer, ensuring that no air bubbles were trapped at the bottom of the gel as this interferes with electrophoresis process. The top compartment was then filled with tank buffer so that it covered the top of the gel and the top electrode. To prepare the sample, $20 \mu \mathrm{g}$ of sample buffer (Appendix 2) was added to $20 \mu \mathrm{g}$ of each protein sample. The samples were then activated by heating them for 10 minutes at $80^{\circ} \mathrm{C}$ in an Eppendorf heater to denature the proteins. $20 \mu \mathrm{g}$ of the protein marker, Dalton VII was also prepared in the same way as the protein samples. A Hamilton syringe was used to load the samples and the Dalton VII marker into the wells in the gel. The tank was connected to a power of 13 pack and the gel was run at $200 \mathrm{~V}$ for approximately 1- 2 hours until the bromo-phenol blue band had reached the bottom of the gel (approximately $0.5-0.8 \mathrm{~cm}$ from the bottom of the gel). The power was then switched off and the tank and the tank buffer from top and bottom compartments were poured away (Skidmore, 2003). The standard fixing solution (Appendix 6) was added to the gel and left for 25 minutes. Then removed and replaced with reconstituted sterling fixative and the gel were fixed for an additional 5 minutes. The gel was then washed in de-ionised water twice for 15 minutes each time. The gel was then immersed in silver staining solution and shacked gently for 10-15 minutes while the gel developed. When the gel had reached the desired intensity the development was stopped by placing the gel in a $5 \%$ acetic acid solution for 3-5 minutes. The gel was then placed in de-ionised water, measured and photographed.

\section{Results}

\subsection{Growth Curve for Capsicum Frutescens Leaves}

As shown in Graphs 1 and 2 (plotted for average lengths and widths of 50 chilli leaves) asigmaoidal growth curve is clearly observed. The standard deviations for leaf length are calculated. From the growth curve, four developmental stages were selected for the further experiments:

1) Days $3(40 \pm 2.73 \mathrm{~mm})$ - stage 1 ,

2) Days $6(60 \pm 3.9 \mathrm{~mm})$ - stage 2 ,

3) Days $9(80 \pm 7.58 \mathrm{~mm})$ - stage 3 and,

4) Days 18 (114.1 $\pm 8.74 \mathrm{~mm})$ - stage 4 .
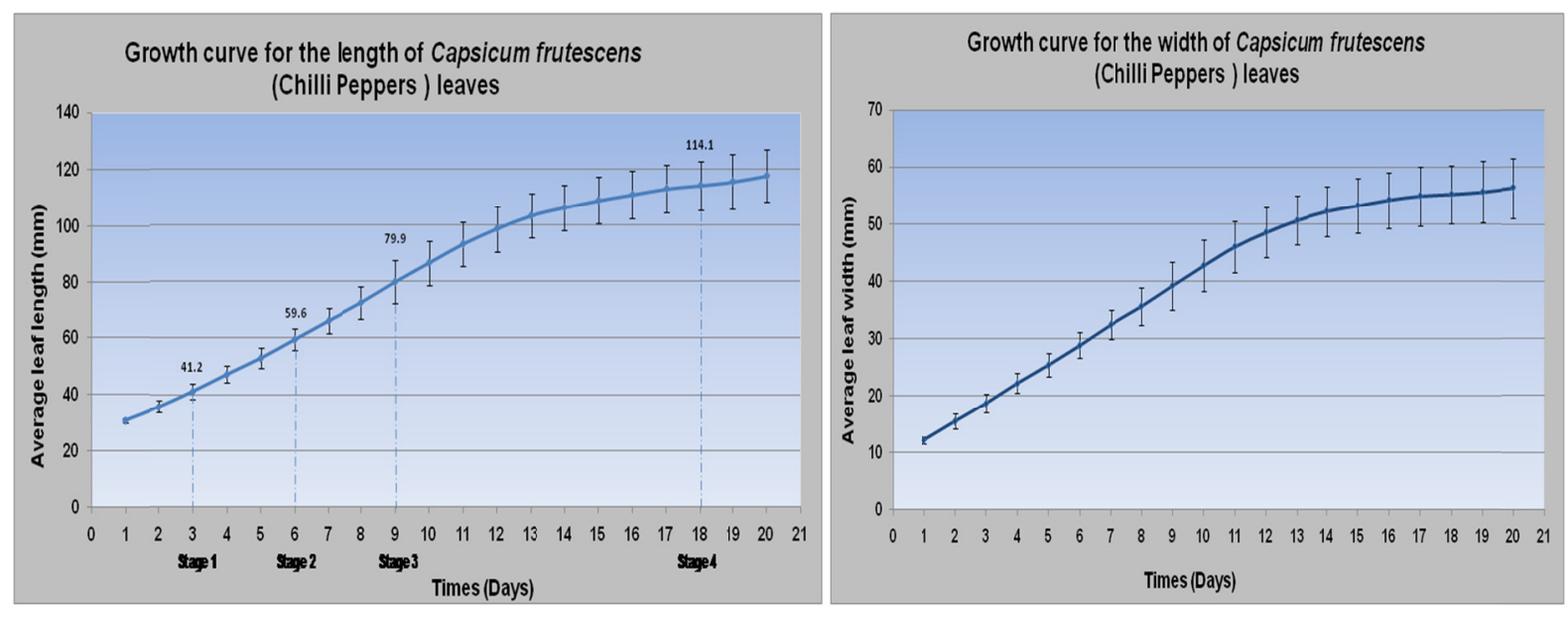

Graph 1. Sigmoidal growth curve representations the average length of chilli leaves with the four developmental stages, $95 \%$ confidence intervals are indicated by bars above and below the curve
Graph 2. Sigmoidal growth curve representations the average width of chilli leaves with the four developmental stages, 95\% confidence intervals are indicated by bars above and below the curve 
Table 1. Stages of Capsicum frutescens leaf development selected for further study

\begin{tabular}{ccccc}
\hline Stage & $\begin{array}{c}\text { No. of days of growth } \\
\text { (from, 30, 31, 32) }\end{array}$ & Mean (mm) & Standard Deviation ( \pm ) & 95\% Confidence Intervals (mm) \\
\hline 1 & 3 & 40 & 2.73 & $\pm 38-42$ \\
2 & 6 & 60 & 3.9 & $\pm 58-62$ \\
3 & 9 & 80 & 7.58 & $\pm 78-82$ \\
4 & 18 & 114.1 & 8.74 & $\pm 110-120$ \\
\hline
\end{tabular}

\subsection{Protein Assay}

A Bovine Serum Albumin standard curve was plotted to determine the protein concentrations of various samples pertaining to stages 1 to 4 . From the four stages, absorbance values were read at the wavelength $595 \mathrm{~nm}$. The samples were then diluted to a concentration of $1 \mu \mathrm{g} / \mu \mathrm{l}$ for the further studies.

Table 2. Protein concentration of samples from the absorbance readings plotted against BSA standard curve

\begin{tabular}{cccccc}
\hline $\begin{array}{c}\text { Tube } \\
\text { No. }\end{array}$ & Sample stage & $\begin{array}{c}\text { Absorbance } \\
\mathbf{( 5 9 5} \mathbf{~ n m})\end{array}$ & Mean & $\begin{array}{c}\text { Protein } \\
\text { concentration } \\
\text { from graph } \\
(\boldsymbol{\mu g} / \boldsymbol{\mu l})\end{array}$ & $\begin{array}{c}\text { Protein } \\
\text { concentration } \\
\text { of sample } \\
\mathbf{( \mu g} / \boldsymbol{\mu l})\end{array}$ \\
\hline 1 & 1 & 0.274 & 0.282 & 4 & 2 \\
2 & 2 & 0.290 & 0.454 & 10 & 4 \\
3 & 3 & 0.448 & 0.672 & & \\
& & 0.662 & 0.667 & 17.5 & 7 \\
4 & 4 & 0.457 & 0.454 & 10 & 4 \\
\hline
\end{tabular}

\subsection{SDS-PAGE Results of C. frutescens Leaf Cell Wall Extracts}

All together a total of ten SDS-PAGE gels were run. The first four attempts produced poor results. In each gel, $20 \mu \mathrm{g}$ of samples was loaded along with $20 \mu \mathrm{l}$ of sample buffer. The initial gels were unsuccessful. So, the samples were spun to a produce clear protein sample. For the effective results, a glass dish was used for staining and all solutions and buffers were made up using steriliseddeionised water. Gel photographs were then taken.

\subsubsection{SDS-PAGE Molecular Weights Calculation}

At the four developmental stages, protein bands molecular weights were determined by measuring the distance travelled by proteins from the top of separating gel buffer to middle of protein band. Relative mobility was calculated as shown below.

$$
\text { Relative Mobility }=\frac{\text { Distance travelled by the protein }}{\text { Distance moved by dye front }}
$$

A calibration curve was then drawn for relative mobility of the marker bands against $\log 10$ values of known molecular weights from the Dalton VII marker. Several bands were developmentally regulated. The protein bands molecular weights were in the range $13.4 \mathrm{KDa}$ to $44.0 \mathrm{KDa}$. Altogether, 14 protein bands are observed, only ten of which were expressed in all the four stages with the molecular weights 13.4, 14.0, 17.6, 18.019 .8 , 21.0,22.5,25.6, 39.0 and 44.0 KDa respectively. Ten protein bands $\mathbf{A}, \mathbf{B}, \mathbf{E}, \mathbf{F}, \mathbf{G}, \mathbf{H}, \mathbf{I}, \mathbf{J}, \mathbf{M}$ and $\mathbf{N}$ were detected in all 4 samples. But, protein bands $\mathbf{C}(36.2 \mathrm{KDa}), \mathbf{D}(27.7 \mathrm{KDa}), \mathbf{K}(16.8 \mathrm{KDa})$ and $\mathbf{L}(16.0)$ were not observed in sample 4, bands $\mathbf{L}(16.0 \mathrm{KDa})$ not detected in sample 2, 3 and 4 (Table 3 ). This infers that the protein $\mathbf{L}$ was developmentally regulated. If any protein missing in the earlier or the later developmental stages, 
is said to be developmentally regulated during leaf developmental process. Proteins A (44.0 KDa), B (39.0 KDa), E (25.6 KDa), F (22.5), G (21.0 KDa), H (19.8 KDa), I (18.0 KDa) J (17.6 KDa), M (14.0 KDa) and N (13.4 $\mathrm{KDa})$ were abundant for all the stages for the developmental process. These variations in expression are clearly indicative of the developmental regulation of these proteins during the leaf development (from stages 1-4) (see Figures 1-4). These variations are due to housekeeping genes as they produce proteins which are necessary for the metabolic functionality of the cell. Proteins accordingly vary with respect to the house keeping genes presence. Examples of housekeeping gens are actin, ubiquitin, GAPDH (Glyceraldehyde, 3-phosphate dehydrogenase) which is vital for glycolytic pathway and albumin that transports compounds throughout the body. Housekeeping genes are vital for structural proteins coding to makeup cytoskeleton like beta-actin and tubulin. These genes are collectively expressed at all the known conditions at a constant level relatively.

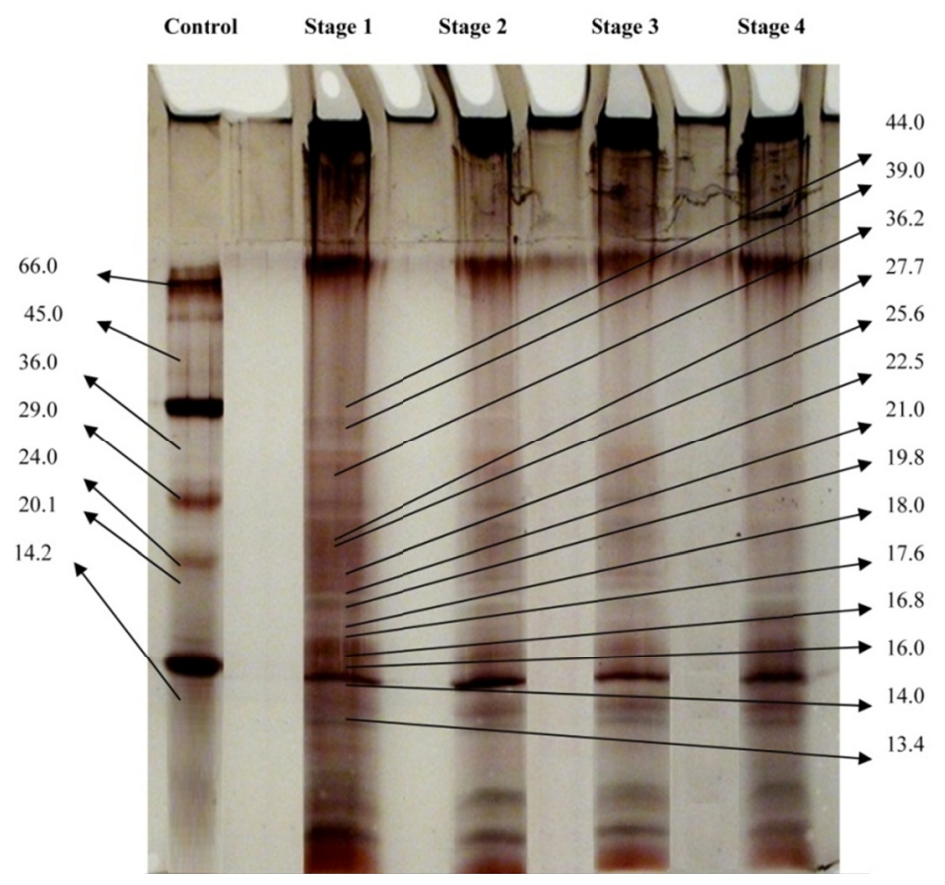

Figure 1. Molecular weights (stage 1): 13.4, 14.0, 16.0, 16.8, 17.6, 18.0, 9.8, 21.0, 22.5, 25.6, 27.7, 36.2, 39.0, $44.0 \mathrm{KDa}$

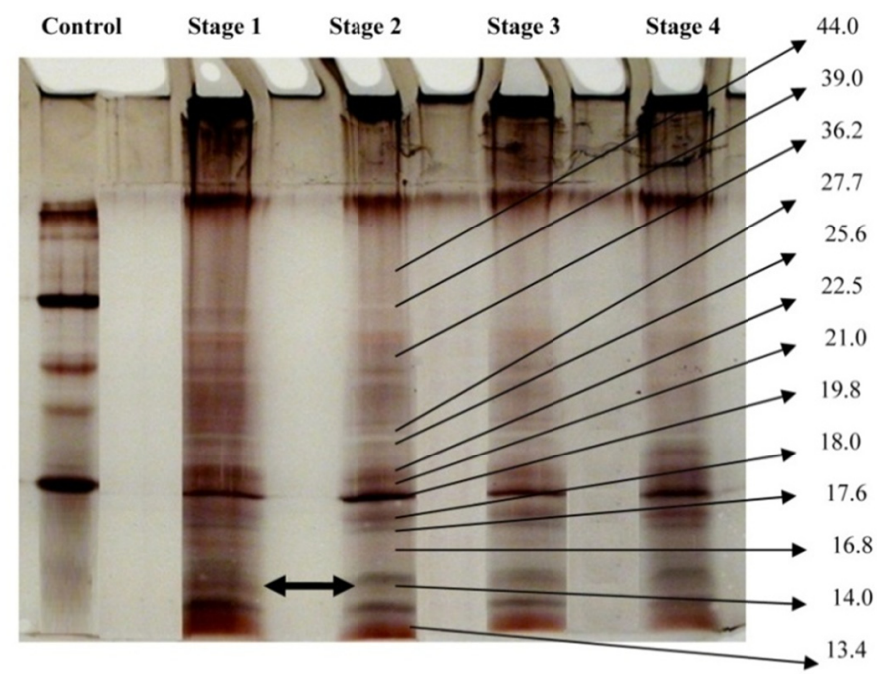

Figure 2. Molecular weights (stage 1): 13.4, 14.0, 16.0, 16.8, 17.6, 18.0, 19.8, 21.0, 22.5, 25.6, 27.7, 36.2, 39.0, $44.0 \mathrm{KDa}$ 


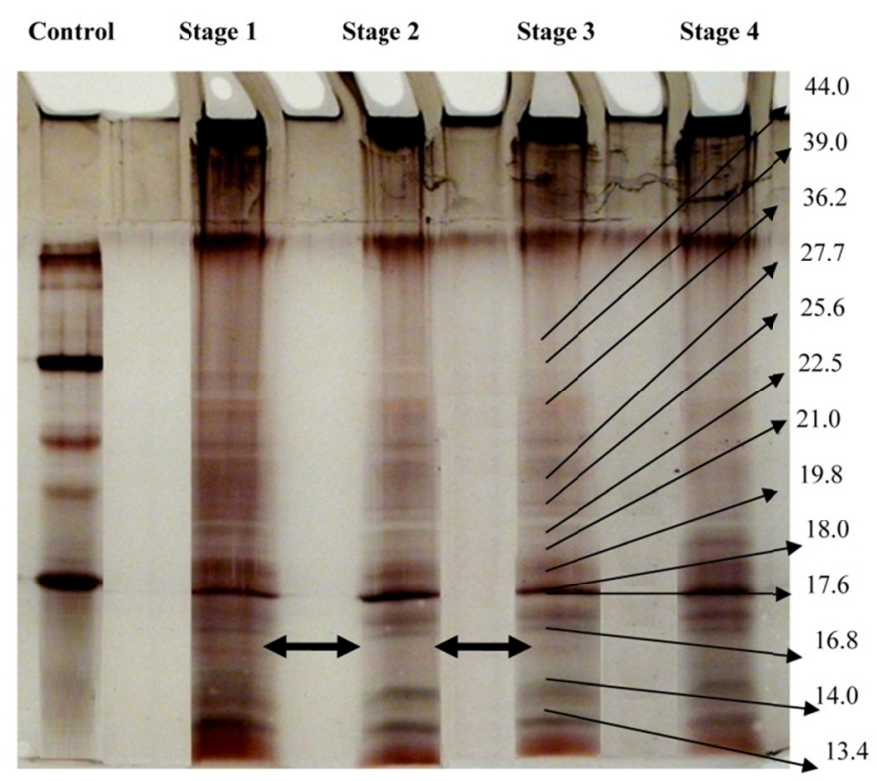

Figure 3. Molecular weights (stage 1): 13.4, 14.0, 16.0, 16.8, 17.6, 18.0, 19.8, 21.0, 22.5, 25.6, 27.7, 36.2, 39.0, $44.0 \mathrm{KDa}$

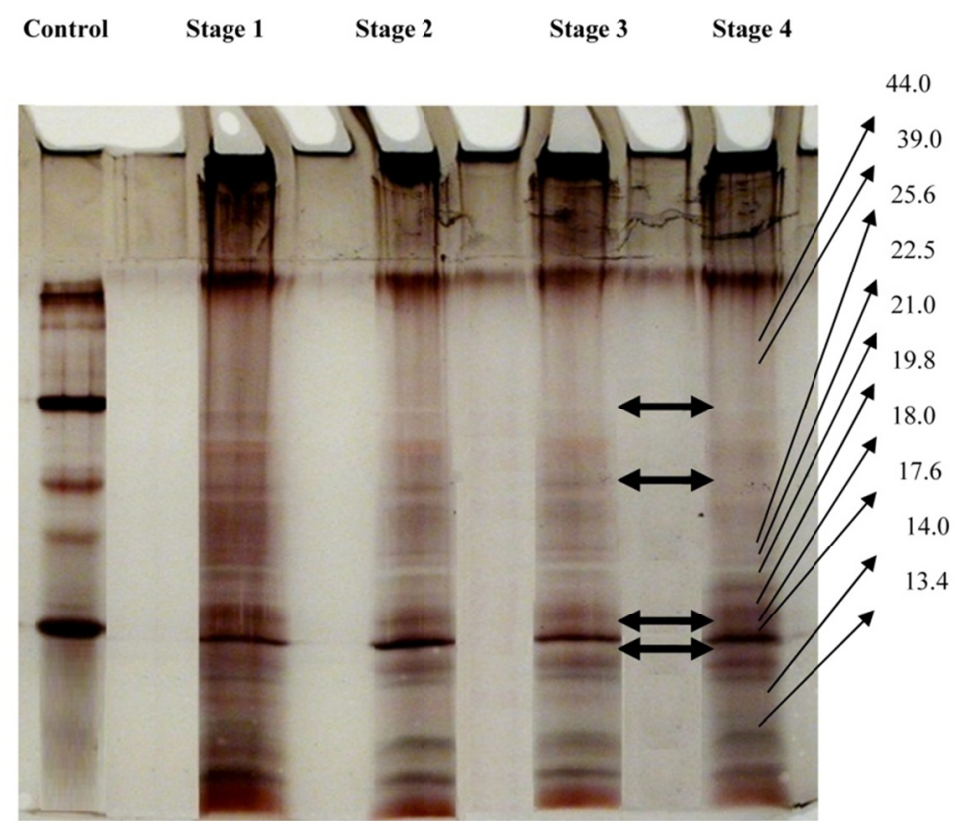

Figure 4. Molecular weights (stage 4): 13.4, 14.0, 17.6, 18.0, 19.8, 21.0, 22.5, 25.6, 39.0, 44.0 KDa 
Table 3. Protein bands present in the gel at the four stages of development. ' $(\mathrm{X})$ ' indicates the presence of a protein band, '(-)' indicates the absence of a protein band

\begin{tabular}{cccccc}
\hline \multirow{2}{*}{$\begin{array}{c}\text { Protein } \\
\text { Band }\end{array}$} & Molecular Weight (KDa) & \multicolumn{4}{c}{ Development Stage } \\
\cline { 3 - 6 } & & Stage 1 & Stage 2 & Stage 3 & Stage 4 \\
\hline A & 44.0 & $\mathrm{X}$ & $\mathrm{X}$ & $\mathrm{X}$ & $\mathrm{X}$ \\
$\mathrm{B}$ & 39.0 & $\mathrm{X}$ & $\mathrm{X}$ & $\mathrm{X}$ & $\mathrm{X}$ \\
$\mathrm{C}$ & 36.2 & $\mathrm{X}$ & $\mathrm{X}$ & $\mathrm{X}$ & - \\
$\mathrm{D}$ & 27.7 & $\mathrm{X}$ & $\mathrm{X}$ & $\mathrm{X}$ & - \\
$\mathrm{E}$ & 25.6 & $\mathrm{X}$ & $\mathrm{X}$ & $\mathrm{X}$ & $\mathrm{X}$ \\
$\mathrm{F}$ & 22.5 & $\mathrm{X}$ & $\mathrm{X}$ & $\mathrm{X}$ & $\mathrm{X}$ \\
$\mathrm{G}$ & 21.0 & $\mathrm{X}$ & $\mathrm{X}$ & $\mathrm{X}$ & $\mathrm{X}$ \\
$\mathrm{H}$ & 19.8 & $\mathrm{X}$ & $\mathrm{X}$ & $\mathrm{X}$ & $\mathrm{X}$ \\
$\mathrm{I}$ & 18.0 & $\mathrm{X}$ & $\mathrm{X}$ & $\mathrm{X}$ & $\mathrm{X}$ \\
$\mathrm{J}$ & 17.6 & $\mathrm{X}$ & $\mathrm{X}$ & $\mathrm{X}$ & $\mathrm{X}$ \\
$\mathrm{K}$ & 16.8 & $\mathrm{X}$ & - & - & - \\
$\mathrm{L}$ & 16.0 & $\mathrm{X}$ & $\mathrm{X}$ & $\mathrm{X}$ & $\mathrm{X}$ \\
$\mathrm{M}$ & 14.0 & $\mathrm{X}$ & $\mathrm{X}$ & $\mathrm{X}$ & $\mathrm{X}$ \\
$\mathrm{N}$ & 13.4 & 14 & 13 & 13 & 10 \\
\hline Number of bands in each stage stages & & & & \\
\hline
\end{tabular}

\section{Discussion}

Leaf is a principle organ of photosynthesis, respiration and is divided into different portions like blade and petiole-stalk. Leaf is responsible for photosynthesis (food manufacture) and respiration (usable energy production). Leaves are the repositories of food and water (Tsukaya, 2002). In response to environmental conditions, leaves themselves modified to various kind of forms to sustain. Leaves are used in multidiscipline fields like food, medicine, fossil fuel and many (Ravishankar et al., 2003; Lozzioet al., 2008). Capsicum is a crop having economic importance around the globe especially in the countries like India, Mexico and China. From the SDS-PAGE results, 14 bands with molecular weights in the range 13.4 to $44.0 \mathrm{kDa}$ were detected. Ten protein bands with molecular weights A (44.0), B (39.0), E (25.6), F (22.5), G (21.0), H (19.8), I (18.0), J (17.6), M (14.0) and $\mathrm{N}$ (13.4) kDa were found to be present in all the four developmental stages and this conveys all these proteins are vitally important throughout the leaf development in all the stages. Protein bands of molecular weights C (36.2), D (27.7), K (16.8) and L (16.0) were not observed in stage 4 and this infers that this protein is required in initial stage of leaf development but not to later stages. Protein band of molecular weight $16.0 \mathrm{kDa}$ was not observed in stage 2, 3 and 4 inferring that this protein is developmentally regulated. These results convey that the proteins were developmentally regulated. A total of ten SDS-PAGE gels were run. Some of the gels were initially run with $4.1 \mathrm{ml}$ and $0.6 \mathrm{ml}$ volume of Acrylamide in separating and stacking gel respectively used. As a result the gels were broken up. Hence the volume of acrylamide increased to $4.6 \mathrm{ml}$ and $0.8 \mathrm{ml}$ of separating and stacking gels by decreasing SDW from $3.3 \mathrm{ml}$ to $2.8 \mathrm{ml}$ in separating and $1.7 \mathrm{ml}$ to $1.5 \mathrm{ml}$ SDW in stacking gel. This helped to obtain a thicker gel that cope up with the samples. Initial gels were not properly washed with standard fixatives, deionised water with surfactant, so gels were not clear. And majorly, air bubbles were formed inside gel matrix that ceased the smooth flow of the samples from cathode to the anode and fetched improper and unclear bands (Butler, 2005; Wilson \& Walker, 2005).

\section{Conclusion}

Capsicum frutescensis an important agro-economic crop which could benefit from the research to improve quality, yields and production levels by using the various plant biotechnological methods. Solanaceaemembers such as Lycopersicum esculentum (tomato), Nicotiana tobaccum (tobacco) and Solanum tuberosum (potato) are the model systems have been subjected to biochemical and immunological investigations (Ochoa-Alejo \& Ramirez-Malagon, 2001). Advanced techniques such as genetic transformation, genetic modification can improve the crop qualities and these crop cells are capable of regenerating organs by cell, tissue and organ 
cultures and eventually to a whole plant in vitro. According to a study done by Ochao-Alejo and Ramirez-Malagon, conferring resistance to pests and diseases to the plants is highly difficult by recombinant DNA techniques. Till now, much progress has been done in terms of genetic improvement of Capsicum. Still a long way is ahead to improve the quality traits. Many efforts are being put to combat various kinds of diseases especially viral induced diseases. But these efforts are still not satisfactory. Various strategies have been employed to protect plants against viruses such as protein mediated resistance and satellite RNA mediated resistance. To block the progress of virus infection, protein based approaches are reliable. In RNA based resistance, viral DNA is degraded by using plants post-transcriptional gene silencing mechanism. Advanced technique like designing artificial microRNA (miRNA) is used against pathogenic viruses. Artificial miRNA down regulates the gene expression in plants. So this technique is exploited to confer resistance in plants to combat against pathogenic virus (Kothari et al., 2010). It could be quite inevitable that all the new cell wall proteins and their genes must be identified and characterised. But the difficulty here is their functions and molecular interactions. Prior to their function, knowing the protein position is a million dollars question. Inculcating mutants by antisense RNA technology is exciting but is a difficult experiment and is raising many concerns regarding ethics. So these concerns must be answered in the upcoming days (Showalter, 1993).

\section{References}

Barceloux, D. G. (2008). Medical toxicology of natural substances: foods, fungi, medicinal herbs, Toxic plants and venomous animals (pp. 71-76). John Wiley and Sons Inc. http://dx.doi.org/10.1002/9780470330319.ch10

Bio-Rad laboratories. (2005). Instruction for the bio-rad protein assay. Retrieved from http://www.bio-rad.com

Butler. J. M. (2005). Forensic DNA Biology, technology, and genetics of STR markers (2nd ed., pp. 313-342). London: Elsevier Academic Press.

Byrne, M. E. (2005). Networks in Leaf development. Current opinion in Plant Biology, 8, 59-66. http://dx.doi.org/10.1016/j.pbi.2004.11.009

Cosgrove, D. J. (2000). Loosening of cell walls by expansins. Nature, 407, 321-326. http://dx.doi.org/10.1038/35030000

Cosgrove, D. J. (2005). Growth of the plant cell wall review. Nature, 6, 850. Retrieved 17th August, 2010, from www.nature.com/reviews/molcellbio

Fleming, A. J. (2002). The mechanism of leaf morphogenesis. Planta, 216, 17-22. http://dx.doi.org/10.1007/s00425-002-0864-8

Gamage. H. K., \& Jesson, L. (2007). Leaf heteroblasty is not an adaptation to shade: seedling anatomical and physiological responses to light. New Zealand Journal of Ecology, 31(2), 245-254.

Kothari, S. L., Joshi, A., kachhwaha, S., \& Ochoa-Alejo, N. (2010). Chilli peppers-A review on tissue culture and transgenesis. Biotechnology Advances, 28, 35-48. http://dx.doi.org/10.1016/j.biotechadv.2009.08.005

Lozzio, M., Tundis, R., Menichini, F., Statti, G., \& Menichini, F. (2008). Influence of ripening stage on health benefits properties of Capsicum annuum Var. Acumunatum L.: In vitro studies. Journal of Medicinal Food, 11(1), 184-189. http://dx.doi.org/10.1089/jmf.2007.638

Ochoa-Alejo, N., \& Ramirez-malagon, R. (2001). In vitro chilli pepper biotechnology. Bio plant, 37, 701-729.

Prasad, B. C. N., Gururaj, V. K., Parimalan, R., Giridhar, P., \& Ravishankar, G. A. (2006). Characterization of capsaicin synthase and identification of its gene (csyI) for pungency factor capsaicin in pepper (Capsicum sps.). PNAS, 103(36), 1315-1320. http://dx.doi.org/10.1073/pnas.0605805103

Ravishankar, G. A., Suresh, B., Giridhar, P., Rao, S. R., \& Johnson, T. S. (2003). Biotechnological studies on Capsicum metabolite production and plant improvement. In De AK, Capsicum: The genus of Capsicum. London: CRC press.

Sanatombi, K., Sen-Mandi, \& Sharma, G. J. (2010). DNA profiling of Capsicum landraces of Manipur, Scientia. Horticulturae, 124, 405-408. http://dx.doi.org/10.1016/j.scienta.2010.01.006

Showalter, A. M. (1993). Structure and function of plant cell wall proteins. The Plant cell, 5, 9-23.

Simonne, A. H., Simonne, E. H., Eitenmiller, R. R., Mills, H. A., \& Green, N. R. (1997). Ascorbic acid and pro-vitamin A content in unusually coloured bell peppers (Capsicum annuum L). Food Campo Anal, 10, 299-311. http://dx.doi.org/10.1006/jfca.1997.0544 
Skidmore, N. (2003). Instruction for the preparation of a SDS-PAGE gel. University of Wolverhampton, labtechnician.

Taiz, L., \& Zeiger, E. (2002). Plant Physiology (3 rd Edition, Chapter 15, pp. 314-338). Sinauer Associates: Inc Publishers.

Tsukaya, H. (2002). Leaf Development: The Arabidopsis Book. American Society of Plant Biologists, Retrieved 15th August, 2010, from http://www.bioone.org/doi/pdf/10.1199/tab.0072

Wilson, K., \& Walker, J. (2005). Principles and Techniques of Biochemistry and Molecular Biology (6th ed., pp. 449-484). New York: Cambridge University Press. http://dx.doi.org/10.1017/CBO9780511813412

\section{Appendix 1. Cell wall extraction buffers}

\section{Stock solutions}

A - 0.5 M EDTA $(500 \mathrm{ml})$

$93 \mathrm{~g}$ of dissodium EDTA

Dissolved slowly in $400 \mathrm{ml}$ of SDW

Adjust $\mathrm{pH}$ to 8.0 with approximately $10 \mathrm{~g}$ of $\mathrm{NaOH}$ pellets

B - 2M NaCI (100 ml)

$11.2 \mathrm{~g} \mathrm{NaCI}$

Dissolved in $100 \mathrm{ml} \mathrm{SDW}$

Autoclave

\section{C - 1M Tris-HCl pH $8.0(100 \mathrm{ml})$}

$12.11 \mathrm{~g}$ Tris base

Dissolved in $80 \mathrm{ml} \mathrm{SDW}$

Adjust $\mathrm{pH}$ with Concentrated HCI

Autoclave

Protein extraction buffer

A-10 mM EDTA

B-10 $\mathrm{mMNaCl}$

C- $0.2 \mathrm{M}$ Tris- $\mathrm{HCl}$ (pH 8.0)

For preparing $1 \mathrm{ml}$ protein extraction buffer

$200 \mu 11 \mathrm{M}$ Tris- $\mathrm{HCl}$ (pH 8.0)

$5 \mu 12 \mathrm{M} \mathrm{NaCl}$

$20 \mu 10.5$ M EDTA

$775 \mu 1 \mathrm{SDW}$

\section{$1 \mathrm{ml}$ Extraction buffer}

$900 \mu 1$ Proteinextraction buffer

$100 \mu 110 \%$ Nonidet

$1 \mu 1 \mathrm{M}$ DTT

Appendix 2. SDS PAGE solutions

Separating gel buffer $(250 \mathrm{ml})$

$45.38 \mathrm{~g}$ Tris base

$0.67 \mathrm{~g}$ EDTA

Dissolve in $125 \mathrm{ml}$ of SDW

Adjust $\mathrm{pH}$ to 8.8 with concentrated $\mathrm{HCI}$

Dissolve $1 \mathrm{~g}$ SDS (Sodium Dodecyl Sulphate) in solution 
Make up volume to $250 \mathrm{ml}$ with SDW

(Adjust $\mathrm{pH}$ before adding SDS as SDS compound will damage the $\mathrm{pH}$ electrode)

\section{Stacking gel buffer $(50 \mathrm{ml})$}

$3.0 \mathrm{~g}$ Tris base

$0.33 \mathrm{~g}$ EDTA

Dissolve in $25 \mathrm{ml} \mathrm{SDW}$

$\mathrm{pH}$ to 6.8 with $\mathrm{HCl}$

Add $0.2 \mathrm{~g}$ SDS

Make up volume to $50 \mathrm{ml}$ with SDW

Tank buffer $(5 \times$ concentrate) $(1000 \mathrm{ml})$

$30 \mathrm{~g}$ Tris base

144 g Glycine

$5 \mathrm{~g}$ SDS

3.72 g EDTA

Make up volume to 1 liter

Do not adjust $\mathrm{pH}$

For use dilute volume (1:4 dilutions with SDW)

\section{Sample buffer $(50 \mathrm{ml})$}

$1.2 \mathrm{~g}$ Tris base

$0.149 \mathrm{~g}$ EDTA

Make up volume to $20 \mathrm{ml}$

Adjust $\mathrm{pH}$ to 6.8 with $\mathrm{HCl}$

$15 \mathrm{~g}$ Sucrose

$2 \mathrm{ml}$ Mercaptoethanol

$2.5 \mathrm{~g}$ Bromophenol blue

$4 \mathrm{~g}$ SDS

Make up volume to $50 \mathrm{ml}$ with SDW

\section{$10 \%$ Ammonium persulphate}

$0.1 \mathrm{~g}$ dissolved in $1 \mathrm{ml} \mathrm{SDW}$

\section{$\underline{4}$ Separating gel solution}

$2.5 \mathrm{ml}$ separating gel buffer

$4.6 \mathrm{ml} 30 \%$ acrylamide, $0.8 \%$ bis-acrylamide

$2.8 \mathrm{ml} \mathrm{SDW}$

$10 \mu 1$ TEMED (NNNN-Tetraethyimethylenediamide)

$100 \mu 1$ 10\% Ammonium persulphate solution

Added in order and used immediately

\section{$\underline{4}$ Stacking gel solution}

$1 \mathrm{ml}$ Stacking gel buffer

$0.8 \mathrm{ml} \mathrm{30 \%}$ acrylamide, $0.8 \%$ bisacrylamide

$1.5 \mathrm{ml} \mathrm{SDW}$

$5 \mu 1$ TEMED

$25 \mu 1$ 10\% Ammonium persulphate solution, added in order and used immediately 
Appendix 3. Bovine Serum Albumin (BSA) protein assay

\begin{tabular}{|c|c|c|c|c|c|c|}
\hline Tube & $\begin{array}{l}\text { Final BSA protein } \\
\text { concentration }(\mu \mathrm{g} / \mu \mathrm{l})\end{array}$ & $\begin{array}{l}\text { Volume of } \\
\text { Stock }(\mu \mathrm{g})\end{array}$ & $\begin{array}{c}\text { BIORAD dye } \\
\text { Reagent } \\
(\mu 1)\end{array}$ & $\begin{array}{l}\text { Volume of } \\
\text { SDW }(\mu l)\end{array}$ & $\begin{array}{c}\text { Absorbance } \\
(595 \mathrm{~nm})\end{array}$ & Mean \\
\hline 1 & 1 & 2 & 200 & 1798 & $\begin{array}{l}0.116 \\
0.122\end{array}$ & 0.119 \\
\hline 2 & 5 & 10 & 200 & 1790 & $\begin{array}{c}0.318 \\
0.33\end{array}$ & 0.324 \\
\hline 3 & 10 & 20 & 200 & 1780 & $\begin{array}{l}0.459 \\
0.451\end{array}$ & 0.455 \\
\hline 4 & 20 & 40 & 200 & 1760 & $\begin{array}{l}0.760 \\
0.752\end{array}$ & 0.756 \\
\hline 5 & 25 & 50 & 200 & 1750 & $\begin{array}{l}0.841 \\
0.853\end{array}$ & 0.847 \\
\hline Control & 0 & 0 & 200 & 1800 & $\begin{array}{l}0 \\
0\end{array}$ & 0 \\
\hline
\end{tabular}

Stock Solution $(\mu \mathrm{g} / \mu \mathrm{l})$ 